\title{
Avoidable Deaths from Smoking: A Global Perspective
}

\author{
Prabhat Jha, MD, DPhil ${ }^{1}$
}

\begin{abstract}
On current consumption patterns, about 400 million adults worldwide will be killed by smoking between 2010 and 2050. Most of these deaths will occur among smokers currently alive. At least half will die at ages 30-69 years, losing decades of productive life. Smoking-attributable mortality has fallen sharply in high-income countries but will rise globally unless today's smokers, most of whom live in lowand middle-income countries, quit smoking before or during middle age. The single most important intervention to raise cessation rates is a large increase in taxes. Tripling excise taxes on tobacco would raise cessation rates and deter smoking initiation. Higher taxes, regulations on smoking and information for consumers could avoid at least 115 million smoking deaths in the next few decades, including at least 25 million cancer deaths and 50 million vascular deaths.
\end{abstract}

Keywords: Tobacco control, global health, smoking, tobacco deaths, low-income countries, middle-income countries, cessation, economics, prices, information, regulation

Suggested Citation: Jha P. Avoidable deaths from smoking: a global perspective. Public Health Reviews. 2012;33:569-600.

\section{INTRODUCTION}

Tobacco use kills about five to six million people annually worldwide, accounting for about 20 percent of all adult male deaths and five percent of adult female deaths, over age $30 .^{1-5}$ On current smoking patterns, annual tobacco deaths will rise to about ten million by 2030. One hundred million tobacco deaths occurred in the $20^{\text {th }}$ century, of which nearly 70 percent took place in high-income countries and in the former socialist economies of

\footnotetext{
${ }^{1}$ Centre for Global Health Research (CGHR), St. Michael's Hospital, Dalla Lana School of Public Health, University of Toronto, Toronto, Canada.

Corresponding Author Contact Information: Professor Prabhat Jha at prabhat.jha@ utoronto.ca; CGHR, St. Michael's Hospital, Dalla Lana School of Public Health, University of Toronto, Toronto M5C 1N8, Canada.
} 
Europe. ${ }^{1,6}$ By contrast, tobacco is expected to kill about one billion people in the $21^{\text {st }}$ century, with most from low- and middle-income countries outside North America and Europe. ${ }^{1}$ Without widespread cessation, about 400 million tobacco deaths will occur between 2010 and 2050, mostly among current smokers. In the second half of the century, an additional 500 million tobacco deaths are expected to occur, mostly among future smokers (Figure 1).

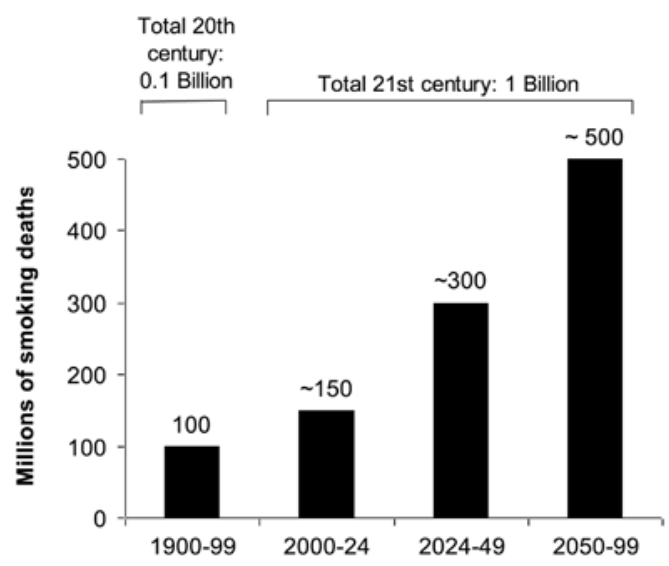

Fig. 1. Projected numbers of deaths from tobacco during the 21 st century. The millions of smoking deaths are shown on the y-axis over time. See text for explanation of how the estimates were derived. Note the differences in the scale used for the time periods of 25, 50 and 100 years.

Here, we argue that widespread use of a few powerful interventions comprising higher tobacco prices, information, and regulations, could prevent several tens of millions of premature deaths over the next few decades. We first present the epidemiology of smoking-related disease, focusing on the harm to smokers themselves, but do not focus on the effects of smoking on others, or in the case for maternal health, the impact of smoking or tobacco use on fetal development and growth., ${ }^{2,4}$ We explain the relevance of the long delay between smoking onset and premature mortality to our understanding of future tobacco-related disease risks, and describe the benefits of cessation. We also outline the economic rationale for intervention in the tobacco markets, and discuss the effectiveness of interventions to rapidly raise cessation rates in low- and middle-income countries. 


\section{EPIDEMIOLOGY}

\section{Current smoking patterns}

This review focuses on smoking because it accounts for the large majority (about $85 \%$ ) of all tobacco produced worldwide, ${ }^{7}$ and because inhaled tobacco causes a greater diversity and incidence of disease compared to chewing tobacco. ${ }^{8-10}$ Active smoking is also far more hazardous than exposure to second-hand smoke, ${ }^{8,911}$ although the latter does contribute significantly to illness. ${ }^{12}$

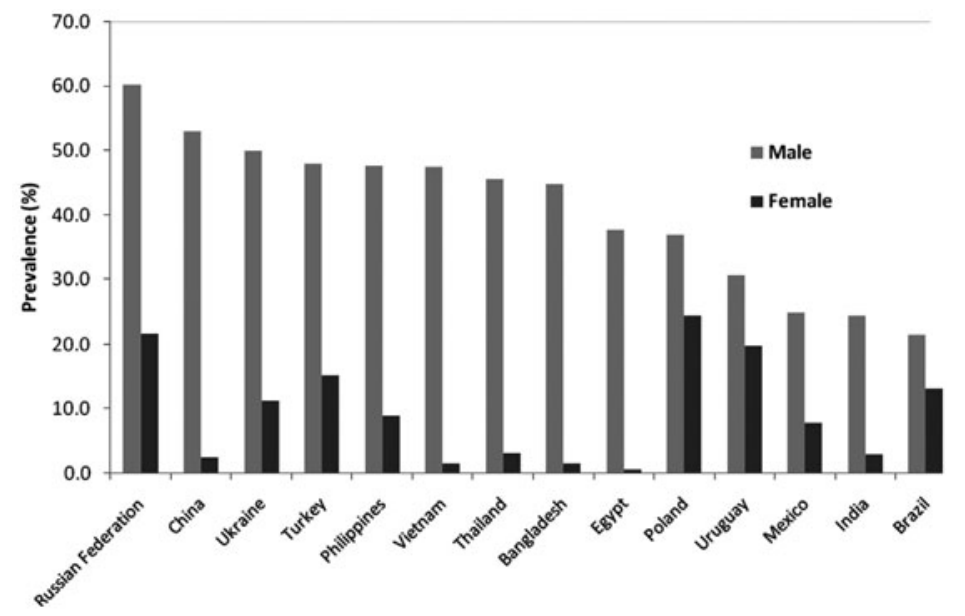

Fig. 2. Smoking prevalence at ages 15 years or older, by gender, in selected countries, 2008-2010.

Source: From the Global Adult Tobacco Surveys. ${ }^{14-27}$

More than 1.1 billion people currently smoke worldwide. Of whom over 80 percent reside in low- and middle-income countries. Based on the 2010 United Nations population estimates, ${ }^{13}$ over 600 million current smokers ${ }^{14-27}$ reside just in 14 countries (Bangladesh, Brazil, China, Egypt, India, Mexico, Philippines, Poland, Russia, Thailand, Turkey, Ukraine, Uruguay, and Viet Nam). Data from the 2008-2010 Global Adult Tobacco Survey for adults aged 15 years and older implemented in these countries indicates that the proportion of adult men who smoke ranges from over 60 percent in Russia, to about 20 percent in Brazil (Figure 2). Among adult women, the proportion of smokers ranges from 24 percent in Poland to 0.5 
percent in Egypt. There are as yet standardized survey data only from school children through the Global Youth Tobacco Survey (GYTS), which reveal significant rates of smoking among school age-children to about age 15 , plus some evidence that the male predominance of smoking is changing. ${ }^{28}$

The per adult consumption number of cigarettes smoked has more than halved in the last two to three decades in the United States, United Kingdom, Canada, France and other high-income countries. ${ }^{29}$ In contrast, male smoking has risen sharply in many low- and middle-income countries such as China and Indonesia (Figure 3). In India, smoking most commonly occurs in the form of bidis, which are smaller than cigarettes and typically contain only about a quarter as much tobacco. Bidis account for approximately 85 percent of total smoked tobacco consumption in India, although cigarettes have been displacing bidis among younger males over the last 12 years. ${ }^{30}$ Brazil, exceptionally, has recorded decreases in the prevalence of adult smoking. ${ }^{31}$

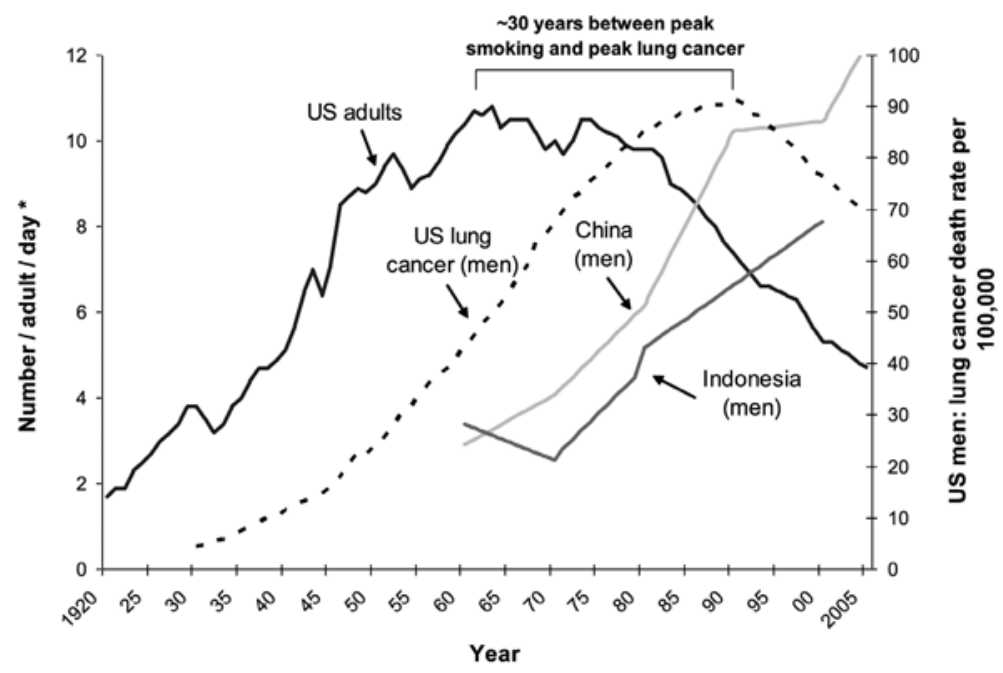

Fig. 3. Trends in cigarette consumption and male lung cancer rates, 1920-2005. The number of cigarettes consumed per adult (men are used as the appropriate denominator for cigarette smoking as few women currently smoke in Asia) and the age-standardised lung cancer rates are shown on the y-axes over time by country. 
Table 1

Prevalence and number of current and ex-smokers among adults in selected countries

\begin{tabular}{|c|c|c|c|c|}
\hline \multirow[b]{2}{*}{ Country } & \multicolumn{2}{|c|}{ Prevalence $(\%)$} & \multicolumn{2}{|c|}{ Number (millions) } \\
\hline & $\begin{array}{l}\text { Current } \\
\text { smokers }\end{array}$ & Ex-smokers & $\begin{array}{l}\text { Current } \\
\text { smokers }\end{array}$ & Ex-smokers \\
\hline Bangladesh (2009)* & 23.0 & 6.0 & 22 & 6 \\
\hline Brazil (2008)* & 17.2 & 18.2 & 25 & 26 \\
\hline China $(2010)^{*}$ & 28.1 & 5.4 & 301 & 57 \\
\hline Egypt (2009)* & 19.4 & 4.4 & 10 & 2 \\
\hline India $(2009)^{*}$ & 14.0 & 2.9 & 111 & 23 \\
\hline $\operatorname{Mexico}(2009)^{*}$ & 15.9 & 14.6 & 11 & 10 \\
\hline Philippines (2009)* & 28.2 & 11.3 & 17 & 7 \\
\hline Poland (2009)* & 30.3 & 21.6 & 10 & 7 \\
\hline Russia (2009)* & 39.1 & 13.8 & 44 & 16 \\
\hline Thailand (2009)* & 23.7 & 12.1 & 12 & 6 \\
\hline Turkey $(2008)^{*}$ & 31.2 & 15.9 & 16 & 8 \\
\hline Ukraine $(2010)^{*}$ & 28.9 & 15.1 & 12 & 6 \\
\hline Uruguay (2009)* & 25.0 & 24.0 & 6 & 6 \\
\hline Vietnam (2010)* & 23.8 & 9.8 & 15 & 6 \\
\hline Canada $(2009)^{* *}$ & 17.0 & 26.0 & 5 & 7 \\
\hline UK (2009)***, & 21.0 & 25.3 & 10 & 13 \\
\hline USA $(2010)^{\frac{1}{2}}$ & 19.3 & 21.1 & 44 & 49 \\
\hline Australia $(2010)^{\S}$ & 18.0 & 24.1 & 3 & 4 \\
\hline $\begin{array}{l}\text { Sub-totals for } \\
18 \text { countries }\end{array}$ & - & - & 674 & 261 \\
\hline
\end{tabular}

Sources:

* GATS (Global Adult Tobacco Survey) (2008-2010)-Country Reports (ages 15+) (compiled from various country reports).

** Canada-CTUMS (Canadian Tobacco Use Monitoring Survey) (2009-2010) (http://www. hc-sc.gc.ca/hc-ps/tobac-tabac/research-recherche/stat/ctums-esutc_2010_graph-eng.php) (ages 15+).

*** UK - General Life Style Survey (GLS), 2009 (ages 16+) (http://www.ons.gov.uk/ons/ publications/index.html?pageSize $=50$ \&newquery=smoking) (in UK, ex-smokers estimate represent ex-regular smokers and never smokers represent never-regularly smoked).

Number of smokers are estimated using the 2010 revision of UN population obtained from http://esa.un.org/unpd/wpp/unpp/panel_indicators.htm (accessed on 5 Sept 2012).

¥ USA - NHIS (National Health Interview Survey) (2010) (ages 18+).

$\S$ Australia - NDSHS (National Drug Strategy Househokd Survey) (2010) (ages 14+). 


\section{Smoking cessation}

To determine smoking prevalence in a population, individuals are divided into three categories: current smokers, ex-smokers and never smokers. Ex-smoking prevalence is a good measure of cessation at a population level. ${ }^{1,32}$ An increase in cessation, along with increasing proportion of never smokers, has dropped adult (age 30 years or more) smoking prevalence in the UK between 1950-2005 from 70 percent to 25 percent in men and 40 percent to 20 percent in women. ${ }^{28}$ There are now twice as many ex-smokers in the UK as smokers among those currently age 50 and older. ${ }^{33}$ Similar increases in cessation have been reported in most high-income countries. ${ }^{32}$ For example, in Canada nearly 1.3 million adults over the age of 15 have quit smoking in the last decade, with increases also in the proportion of never smokers. In contrast, the prevalence of male ex-smokers in most lowand middle-income countries is low: below ten percent in China, ${ }^{34}$ Vietnam ${ }^{35}$ and India ${ }^{36-37}$ (Figure 4). Even these low figures may be falsely elevated because they include people who quit because either they are too ill to continue or because of the early symptoms of tobacco-attributable illness, such as respiratory disease.

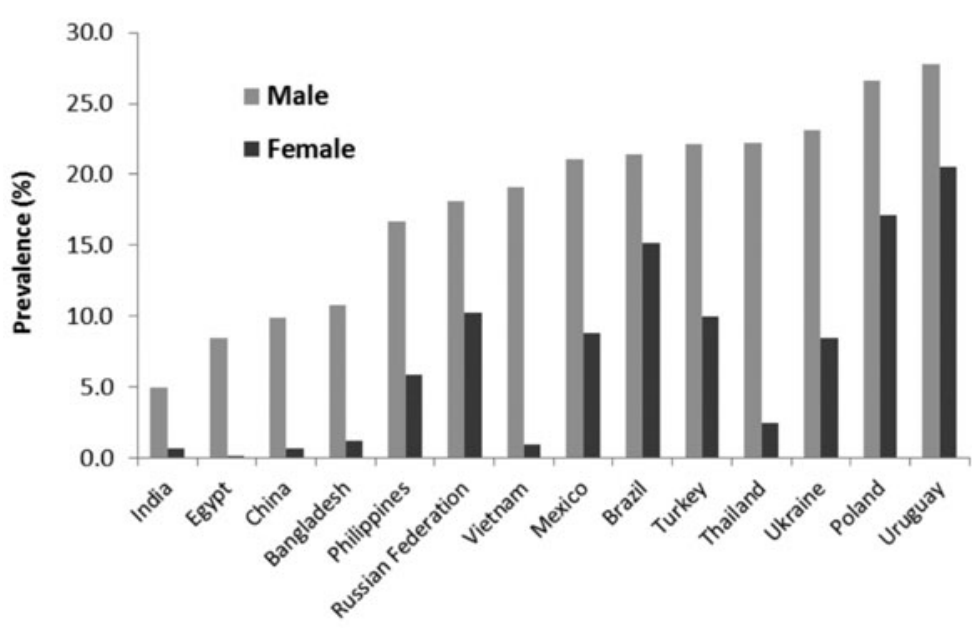

Fig. 4. Ex-smoking prevalence at ages 15 years or older among males in selected low- and middle-income countries, 2008-2010.

Source: From the Global Adult Tobacco Surveys. ${ }^{14-27}$ 


\section{Importance of prolonged smoking on disease risks}

The vast majority of the world's smokers today are below age $35 .{ }^{32}$ For these individuals, a proper understanding of the hazards of continued smoking, and the corresponding benefits of cessation, must include an appreciation for the remarkably long delay between cause and full effect. ${ }^{38,39}$ Indeed, the full effects of smoking can take 50 years to measure in individuals and up to 100 years to measure in populations.

Widespread automation of cigarette production in the early $20^{\text {th }}$ century turned cigarettes into a global commodity. Lung cancer was a rare disease prior to World War II, and the large increase in lung cancer rates lagged behind the onset of consumption by three or more decades. Among British doctors who were born in the first few decades of the $20^{\text {th }}$ century (19001930) and followed by those born in the second half of it (1951-2001), death rates were three times higher among doctors who smoked than those who did not. ${ }^{40}$ Furthermore, the smoker versus non-smoker relative risks of death became more extreme between in the period 1981-2001 than they were between 1951-1980. ${ }^{41}$ Prolonged smokers lost about ten years of life compared to non-smokers. Most, but not all, of the excess deaths from all causes among smokers was due to smoking, as there were no material differences among smokers, non-smokers and ex-smokers in education, drinking and obesity. Similarly, the main increase in male cigarette smoking in the US occurred from 1920-1940, and peaked at about 13 cigarettes per adult male only around $1960 . .^{28,42}$ Yet the rates of male lung cancer in middle age (defined here as about 30-69 years) and at older ages, almost all of which are due to smoking, peaked almost 30 years later (Figure 3). ${ }^{42-45}$ Note that long cancer rates at younger ages (such as 35-44 years) reflect more recent smoking in the population.

The full effects of smoking have not yet been observed in low- and middle-income countries. China has over 300 million smokers ${ }^{16}$ and India has over 120 million smokers, ${ }^{18}$ most of whom are male (Figure 2). The mean consumption among Chinese men was one, four, and ten cigarettes per day in 1952, 1972 and 1992, respectively, which are comparable to increases reported 40 years earlier in the US..$^{46,47}$ Moreover, China reports a marked increase in cigarette production since 2000, which might be from increased smoking among younger adults. India's per capita adult male consumption is over six bidis or cigarettes per day, although there is some uncertainty in this, particularly for bidi use. ${ }^{37}$ This is comparable to the per capita adult consumption in France prior to 1990, and higher than that seen for adults today in Canada, which has declined from about 11 cigarettes per capita in 1960s to below five in $2010 .{ }^{29}$ 


\section{Effects of cessation on lung cancer and total deaths}

Widespread smoking cessation in high-income countries has afforded researchers the opportunity to study the impact of quitting at various ages on the risk of death from tobacco-attributable diseases. UK doctors who quit smoking before the onset of major disease avoided most of the excess hazards of smoking. In comparison to those who continued smoking, the average gain in life expectancy for those who quit smoking at 60, 50, 40, and 30 years of age, was about three, six, nine, and nearly ten years, resnectivelv ${ }^{40}$

UK

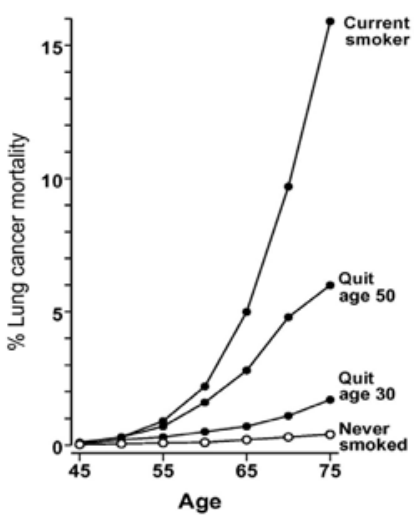

US

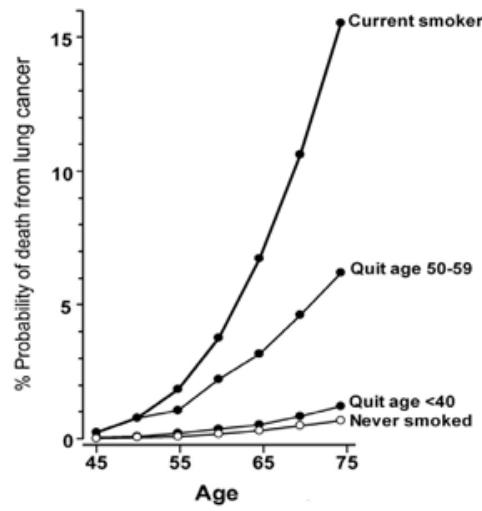

Fig. 5. Risk of death from lung cancer in smokers and ex-smokers. The age-specific probability of death from lung cancer for the US and UK, stratified by continued smoking or cessation at various ages are shown on the y-axes. UK data are from retrospective studies, ${ }^{33}$ courtesy of Richard Peto and Jill Boreham. Only selected smoking categories are displayed (never, stopped within 5 years of stated age, continued), and almost all smokers had used cigarettes. In each age range the relative risks match those in a case-control study of smoking, and an appropriately weighted average of the absolute risks matches the national lung cancer death rates. The US data are from the American Cancer Society prospective study of 1.2 million subjects during the first 10 years of follow-up, courtesy of Michael Thun. ${ }^{42}$ They omit the earlier years of follow-up (1981-83). Only selected smoking categories are displayed (never, stopped within 5 years of stated age, continued), and almost all smokers had used cigarettes. A minority of lung cancers is not due to smoking, but the US rates of lung cancer not due to smoking have changed little from the 1960s to $1990 \mathrm{~s} .{ }^{43,60,127} \mathrm{~A}$ variety of genetic factors have been recently suggested that modestly predict lung cancer risk among smokers and non-smokers. ${ }^{128}$ However, it is improbable that marked shifts in genetic susceptibility have occurred, and even if they had, such shifts would not likely explain the dramatic changes in lung cancer seen over a few years or decades..$^{39,42}$ 
Cessation before middle age prevents more than 90 percent of the lung cancer mortality attributable to smoking, with quitters possessing a pattern of survival similar to that of persons who have never smoked. In the UK, among those who stopped smoking, the risk of lung cancer fell steeply with the amount of time since cessation. ${ }^{33}$ For men who quit at ages 50,40, and 30 , the cumulative risks of lung cancer mortality by age 75 were six percent, three percent, and two percent, respectively. This contrasts greatly with the 16 percent cumulative risk for continuing smokers. Similar reductions in risk of death from lung cancer have occurred in the US among men (Figure 5 ) and women. ${ }^{42}$ The US study showed that few of those who quit smoking would restart. The absolute mortality reduction from cessation may be even greater for other diseases (particularly vascular diseases) than for lung cancer in the first decade or two after stopping smoking. ${ }^{40}$ Similar results on reductions in lung cancer risk among ex-smokers are seen in Poland. ${ }^{48}$ In Germany and Italy, the excess lung cancer mortality avoided among men who quit smoking by age 40 was 91 percent, and 80 percent, respectively. ${ }^{49}$

\section{CURRENT AND FUTURE DISEASE RISKS FROM SMOKING}

In this section, we briefly examine current cancer and total mortality, which reflects past exposure to smoking. Currently, about 70 percent of the 40 million deaths among adults over age 30 years worldwide are due to cancer, vascular and respiratory diseases, and tuberculosis, ${ }^{50}$ each of which are made more common by smoking. ${ }^{8-11}$ Smoking currently causes about five to six million deaths annually worldwide from all causes (Table 2). ${ }^{2}$ About 50 percent of all smoking deaths occur in low-income countries.

In 2001, cancer caused about 2.2 million male deaths and 1.6 million female deaths worldwide at ages $30-69$ years. ${ }^{50}$ At these ages, smoking is estimated to cause about 31 percent and six percent of all cancer deaths in men and women, respectively. There has been a marked drop in male smoking deaths from cancer (and all causes) between 1975 and 2005 in the UK and the US..$^{44,45}$ The 1975 male deaths reflected deaths among men who began to smoke about 1920-1940, near the peak of smoking rates in both countries, when cessation was uncommon. Thus, by 1975, smoking accounted for more than 50 percent of all male cancer deaths and 34-44 percent of deaths from all causes in middle age. By 2005, male cancer deaths from smoking fell to 23-26 percent of all UK and US male cancer deaths, and smoking deaths from all causes also fell. This decline was caused by a drop in the proportion of men who began smoking in 19501970. Also a substantial proportion of this cohort of men ultimately quit 
smoking. The cancer and all-cause death rates from smoking among UK and US females peaked much later, around 1995, but have declined since.

\section{Table 2}

Deaths in middle age men and women from all causes (in thousands), attributed to smoking in selected countries and worldwide

\begin{tabular}{|c|c|c|c|c|}
\hline \multirow[b]{2}{*}{$\begin{array}{l}\text { Country or region (year) } \\
\text { age group }\end{array}$} & \multicolumn{2}{|l|}{ Men } & \multicolumn{2}{|l|}{ Women } \\
\hline & $\begin{array}{l}\text { Smoking deaths/ } \\
\text { all causes deaths }\end{array}$ & $\%$ & $\begin{array}{r}\text { Smoking deaths/ } \\
\text { total deaths }\end{array}$ & $\%$ \\
\hline \multicolumn{5}{|l|}{ World (2001) } \\
\hline Age $30-69^{3}$ & $2309 / 12263$ & 19 & $489 / 8088$ & 6 \\
\hline \multicolumn{5}{|l|}{ High-income } \\
\hline United Kingdom (1975) & $62 / 142$ & 44 & $15 / 85$ & 18 \\
\hline Age $35-69^{43}$ (2005) & $18 / 78$ & 23 & $11 / 51$ & 21 \\
\hline United States (1975) & $157 / 457$ & 34 & $40 / 262$ & 15 \\
\hline Age $35-69^{43}(2005)$ & $113 / 432$ & 26 & $73 / 284$ & 26 \\
\hline \multicolumn{5}{|l|}{ Low- or middle-income } \\
\hline $\begin{array}{l}\text { India }(2010) \\
\text { Age } 30-69^{36}\end{array}$ & $579 / 2882$ & 20 & $93 / 2002$ & 5 \\
\hline $\begin{array}{l}\text { China (2000) } \\
\text { Age } 40+{ }^{46}\end{array}$ & $538 / 4172$ & 13 & $135 / 4348$ & 3 \\
\hline
\end{tabular}

Where reliably measured, the proportion of cancer deaths currently due to smoking also appears to be substantial in low- and middle-income countries..$^{36,46,51}$ In China, smoking caused about 28 percent of cancer deaths in men and six percent in women aged 40 or older in $2000 .^{46,51}$ In India, about 32 percent and six percent of cancer deaths in men and women ages 30-69 years, respectively, are caused by smoking. ${ }^{36,52}$ Smoking appears to synergise chronic viral infections that cause cervical cancers. ${ }^{53}$

Smoking causes about three times as many non-cancer related deaths as it does cancer deaths. Cardiovascular disease is the leading cause of smokingattributable deaths worldwide, and accounts for about 1.5 million smoking deaths annually, of which 0.8 million deaths are from acute heart attack. ${ }^{2,50}$ Smoking is a significant risk factor for both fatal and non-fatal heart attack and stroke. ${ }^{911,54,55}$ In high-income countries, about half of the male and a third of the female deaths from chronic lung disease are due to smoking. ${ }^{45} \mathrm{In}$ China, chronic lung disease accounted for nearly half of all tobacco deaths among men age 30-69 years in 1990. ${ }^{46}$ Among those aged 30-69 years in India, over 30 percent of deaths among men and ten percent of the deaths among women from chronic lung disease are due to smoking in $2010 .{ }^{36}$ 
In both countries, smoking appears to increase the high background rates of chronic lung disease caused by indoor (not ambient) air pollution..$^{56}$

Sir Richard Doll, the late, renowned epidemiologist, observed an association of smoking with tuberculosis in the 1950 s in the UK, ${ }^{57}$ but widespread tuberculosis treatment caused the disease to become too rare to study in high-income countries. Hence the association with smoking was largely forgotten. ${ }^{8}$ More recently, increased risks of tuberculosis death and non-fatal tuberculosis among smokers have been observed in countries where tuberculosis remains common; most notably in India. ${ }^{36,58}$ In India, smoking accounts for nearly 40 percent of tuberculosis deaths among middle-aged males, or about 120,000 deaths.$^{36}$ Sub-clinical infection with the tubercle bacillus is widespread and smoking appears to facilitate progression from silent to active clinical disease..$^{36,58,59}$ Thus smoking might contribute to the spread of tuberculosis infection to others.

\section{Overall current smoker: non-smoker mortality risks}

Provided due allowance is made for the long delay between smoking onset and disease, reasonably consistent quantitative estimates of risk emerge: about one in two of all long-term smokers worldwide are killed by their addiction. ${ }^{8,10,36,40,43-47,51,52,60,61}$ It is already apparent that a substantial portion of tobacco deaths worldwide occur in middle age (defined as 30-69 years): 50 percent in the US and UK, ${ }^{43} 50$ percent in China ${ }^{46,51}$ and a surprisingly high 70 percent in India. ${ }^{36}$ Relative to non-smokers in India, male bidi smokers lose roughly six years, female bidi smokers lose about eight years, and male cigarette smokers lose about ten years of life. ${ }^{36}$ The ten year loss of life among Indian male cigarette smokers is already about as extreme as that observed among UK doctors ${ }^{40}$ who had started smoking early and stayed as life-long smokers. These high risks for the Indian smoker are seen despite the fact that average number of cigarettes smoked in India is less than in the UK and despite the fact that men in India start smoking at later ages than do men in the UK.

At present, about 80 percent of worldwide smoking deaths occur in men, ${ }^{2}$ but this is chiefly because men who died recently smoked more commonly and more intensively when they were young than did the female smokers. The smoker versus non-smoker mortality risks in US women after 2000 are marginally greater than in men. ${ }^{61}$ Additionally, the consequences of smoking vary by socioeconomic group. For example, in several highincome countries and Poland, smoking deaths were shown to account for at least half of the differences in middle age risk of death between rich, educated men and poorer, less educated men. ${ }^{62}$ 


\section{Comparison of smoking and obesity mortality risks}

Studies of tens of thousands of deaths have reliably assessed mortality from adult obesity and from persistent smoking in developed countries. ${ }^{63}$ In the Prospective Studies Collaboration study ${ }^{64}$ of 70,000 deaths in 900,000 adults, an increase of two units in the body-mass index (BMI; the weight in kilograms divided by the square of the height in meters) among men who were overweight, reduced life span by one year (mostly from an increase in vascular disease death rates). This loss of one year of life was comparable to the reduction in life span with an increase of ten percent in the prevalence of smoking seen among UK doctors (Figure 6)..$^{40}$ Moderate obesity (overweight, defined as BMI range 30-35, mean 32) shortens life expectancy by approximately three years. Only among the small minority of adults with severe obesity (BMI range 40-50, mean 43) was the loss of life comparable to the ten years lost for being a life long smoker. Thus, stopping smoking (which is widely practicable) can lead to a gain of about ten years in life expectancy; far more than smokers could expect from weight control (which is currently far less practicable). Note that the comparisons between the morbidity or health care costs of obesity and smoking are quite different to those examining mortality. ${ }^{65}$
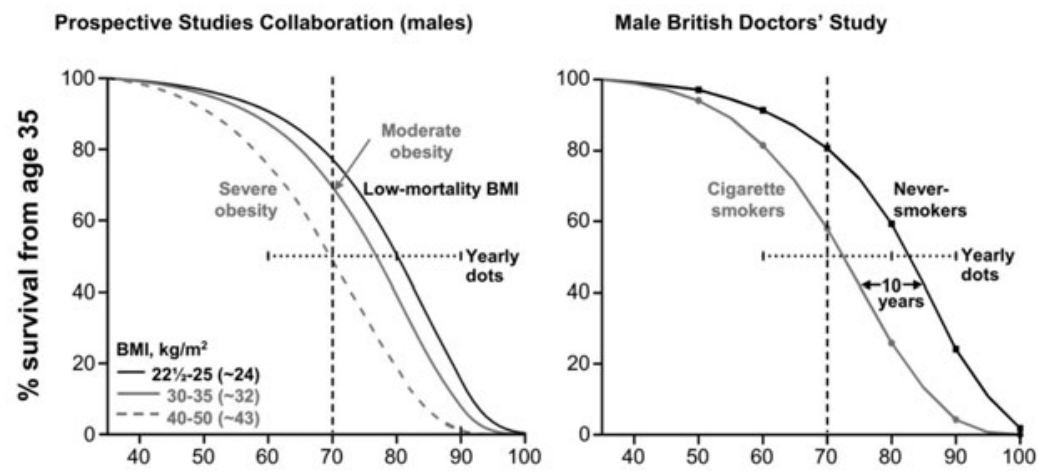

Age (years)

Fig. 6. Mortality risks from smoking and obesity. Male survival, ages 35-100: severe obesity and cigarette smoking each shorten life expectancy by $\sim 10$ years, and moderate obesity shortens it by $\sim 3$ years; so, $2 \mathrm{~kg} / \mathrm{m}^{2}$ extra BMI (if overweight) or a $10 \%$ prevalence of smoking shortens it by $\sim 1$ year. Left: Prospective Studies Collaboration analyses of BMI among males; effects among females are not greater. ${ }^{64}$ Right: Analyses of persistent cigarette smoking among male British doctors. ${ }^{40}$ 


\section{Future risks from smoking}

The future risks of smoking among men in low- and middle-income countries and women worldwide will depend on the duration of smoking (and cessation rates) in the population, variation in the diseases which are made common by smoking, and in the products and patterns of smoking. First, the full effects of smoking will be only apparent when the death rates from smoking in middle age among those who have started smoking as young adults rise 30-40 years later. Death rates from smoking in older age will rise only about 20 years after this. ${ }^{39}$ For example, of all US male deaths at ages 35-69, the proportion attributable to tobacco in 1950 was only 12 percent, rising to 33 percent in 1990, when the increase in US male tobacco deaths had been completed (about three decades after peak male tobacco consumption).$^{43}$ At present, there is some variation in the proportion of male smokers currently killed, being "only" 25 percent in China in 2000, ${ }^{46,51}$ and about 40 percent in India in 2009. ${ }^{36}$ The higher risks among Indian males may reflect the fact that tuberculosis is more common in India than in China, as well as more prolonged smoking (smoking prevalence is higher among Chinese males but they have taken up smoking more recently than their Indian counterparts). The Chinese risks are likely to rise when the smokers who have been smoking throughout the decades from early adult life reach middle age. Second, average daily consumption of cigarettes or bidis is generally lower in low- and middle-income countries than in highincome countries ${ }^{1,32,39}$ and the age of onset of smoking is usually later. Chinese men, however, have begun to start as young as US men. ${ }^{34}$ If similar shifts to smoking at younger ages occur in India and other populations, the hazards of smoking will be greater. Indeed, the future mortality risks from 2010-2050 in China and India might be greater than that observed during the 1940-1980 period in the UK or the US.

Third, in India's case, a major shift from bidis to cigarettes appears to be underway, ${ }^{30}$ and if true, such a shift would substantially raise mortality risks. A large national study of smoking and mortality found that the relative risk of death from any medical cause depended on whether bidis or cigarettes were smoked and the amount smoked (Figure 7) ${ }^{36}$ The risk ratio for a given number of bidis or cigarettes smoked was greater for cigarettes than for bidis. For example, the relative risk of smoking one to seven bidis per day was 1.3 compared to the relative risk of 1.8 from smoking the same number of cigarettes per day. However, for both bidis and cigarettes, more daily smoking meant higher death risks, with particularly elevated risk ratios for smoking eight or more cigarettes a day (akin to the daily amount among smokers in western countries). 


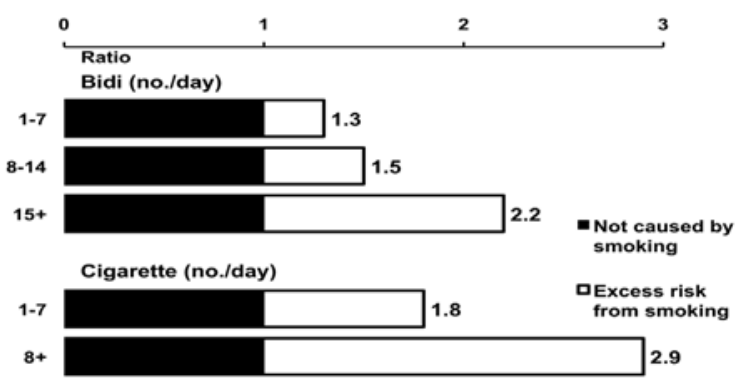

Fig. 7. Relative Risk of Death by Amount and Type of Smoked Tobacco in Indian Men Aged 30-69. The relative risks are derived from a large nationally representative case control study. ${ }^{36}$ The risks are adjusted for education, alcohol use and age.

\section{Projected future death estimates}

Plausible projections of future smoking deaths rely on smoking prevalence and uptake (cessation is minimal in low- and middle-income countries), growth in population and growth in the age-specific tobacco-attributable death rates. Sir Richard Peto ${ }^{6}$ estimates that global tobacco deaths will reach about 450 million between 2000 and 2050. His calculation is based on the following. About 100 million people a year reach adult life worldwide. Current smoking uptake patterns suggest that there are about 30 million new smokers a year (i.e., about $50 \%$ of the young men, and $10 \%$ of the young women). ${ }^{28}$ Most will continue as cessation is uncommon currently outside high-income countries (Figure 4). ${ }^{32}$ Even assuming a large number, say ten of the 30 million do quit (or equivalently that the smoker versus non-smoker risks of eventual death are "only" 1 in 3 versus 1 in 2), then eventually ten million people a year will be killed by smoking. Worldwide annual tobacco mortality will rise to about ten million a year or 100 million per decade around 2030, with some further increases in later decades. ${ }^{6}$ During the 25-year period from 2000-2025, there would be about 150 million tobacco deaths or about six million deaths per year on average; from 2025-2050, there would be about 300 million tobacco deaths, or about 12 million deaths per year. Further estimations are more uncertain, but based upon current initiation and cessation rates and projected population growth, from 2050-2100 there would be, conservatively, an additional 500 million tobacco deaths (i.e., average of 10 million deaths per year). Of the estimated one billion smokingattributable deaths in this century, most will be in low- and middle-income countries. In contrast, there were "only" 100 million tobacco deaths in the $20^{\text {th }}$ century, mostly in high-income and Eastern European countries who took up smoking en masse generally before or around World War II. 
Comparable projections for the next three to four decades have been made by others, ${ }^{1,5,66}$ and the projections are consistent with emerging epidemiological studies in China, ${ }^{46,47,51}$ and India ${ }^{36,52}$ Annual tobacco deaths in China are projected to rise to two million by $2025,{ }^{46,47}$ when the young adult smokers of today reach middle age. Similarly, at current risks, India will have one million annual deaths during the $2010 \mathrm{~s}^{36}$ and this number will rise with population growth. Similar growth in other populations in Asia, Eastern Europe, Latin America, the Middle East and, less certainly, subSaharan Africa, suggest that Peto's estimates of 50-60 million smoking deaths from 2000 to 2010 and about 400 million tobacco-attributable deaths from 2010 to 2050, are plausible. Indeed, the chief uncertainty is not if tobacco deaths will reach about ten million a year, but when, with the most likely scenario being around 2030.

\section{ECONOMIC RATIONALE FOR GOVERNMENT INTERVENTION IN TOBACCO MARKETS}

The public health argument for intervention in tobacco to reduce deaths could not be clearer. However, the tobacco industry and some economists have argued that increased taxation (and some other regulations on tobacco use) is inefficient and unwarranted on economic grounds. ${ }^{67}$ They claim that smokers smoke with full information about its health consequences and take into account the costs and benefits associated with its consumption. However, in practice, the market for tobacco products is characterised by at least three "market failures" ${ }^{68-70}$ Two market failures relate to information: i) most consumers do not have full knowledge of risks associated with the consumption of tobacco, and ii) consumers, especially young smokers, underestimate the risk of addiction to tobacco. In India, few smokers know that 70 percent of smoking deaths occur during productive middle age or that the average years of life lost from smoking is as great as ten years, ${ }^{36}$ and less than 50 percent know that smoking is a cause of stroke ${ }^{18}$ and low proportion of adults in China know that smoking is a cause of heart attack. ${ }^{16}$ In China fully 61 percent of smokers thought tobacco did them no or little harm. ${ }^{34}$ The lack of information on the full risks of smoking paired with the strongly addictive nature of manufactured smoked tobacco results in smokers facing high costs (withdrawal symptoms and physical distress) if they try to quit. In high-income countries with good information on smoking hazards, over 80 percent of adult smokers wish they had never started. Thus, there is no comparable consumer product that carries such severe health risks from continued use, causes regret among informed consumers, and has 
high costs from the withdrawal of its use. Moreover, the tobacco industry specifically engineers cigarettes to be addictive, and designs reinforcing media messages and consumer signals to maintain this addiction. ${ }^{71}$

The third market failure arises from health externalities from exposure to tobacco smoke and some financial externalities due to public spending to treat diseases caused by smoking. Six percent to 15 percent of health spending is estimated to go toward tobacco-related diseases in developing countries. ${ }^{72}$ The direct cost of treating four major tobacco related diseases in India amounted to United States dollars (USD) 1.2 billion, or 4.7 percent of India's national health care expenditure in $2004 .{ }^{73}$ Of course, the adage that the cheapest patient is a dead patient also applies to smoking-related deaths, and indeed some economists have argued that the death of smokers saves money for others in pension schemes. ${ }^{74}$ However, this argument relies on the false assumption that smokers are fully informed about their consumption choices. Moreover, the costs to households who lack formal insurance schemes or pensions and in whom smoking-related diseases leads to poverty or borrowing to treat the sick and loss of intergenerational wealth transfers is likely to be large. A recent study finds that after accounting for direct expenditure on tobacco by Indian households in 2004, tobacco consumption in India impoverishes roughly 15 million people. ${ }^{75}$ Households with a smoker have worse child health outcomes, including lower immunisation rates in children. ${ }^{76,77}$

The biggest cost, of course, is the value of life foregone among smokers who wish to quit, but struggle against the strongly addictive properties of tobacco. Newer economic models that incorporate such real preferences ${ }^{78,79}$ find a strong case for government intervention, and also find that taxation effectively increases the welfare of smokers. In countries with good information, the vast majority of smokers themselves support much higher taxation on tobacco products. ${ }^{80}$

\section{HOW CAN WORLDWIDE CESSATION RATES BE RAISED RAPIDLY}

Cessation by today's smokers is the only practicable way to avoid a substantial proportion of tobacco deaths worldwide before 2050. Halving the worldwide per capita adult consumption of tobacco by 2020 (akin to the declines in adult smoking in the UK over the last three decades) would prevent about 160-180 million tobacco deaths over the next few decades. ${ }^{5,43}$ In contrast, halving the percentage of children who become prolonged smokers (from about $30 \%$ to $15 \%$ over two decades) would prevent some 20 million deaths over the next few decades, but its main effect would be to lower mortality rates in 2050 and beyond. . $^{1,5,6}$ 
Aggressive taxation is the key strategy for low-and middle-income countries to reduce smoking at a rate faster than that achieved by highincome countries. Powerful policy interventions to tax and regulate consumption and to inform consumers have reduced consumption in most high-income countries. ${ }^{28,33,68}$ The US and UK each took about 35 years and Canada about 25 years to halve per adult cigarette consumption (from about 10 per adult per day to about 5). ${ }^{28}$ However, France took only 15 years to halve consumption. ${ }^{81}$ France's uptake of smoking was chiefly after the Second World War and its prevalence rose until the mid-1980s. From 1990 to 2005, cigarette consumption fell from about six cigarettes per adult per day to three cigarettes per adult per day (Figure 8). This sharp decline was mostly due to a sharp increase in tobacco taxation starting in 1990 under the then president Jacques Chirac. These price increases raised the inflationadjusted price threefold. Among men, the corresponding lung cancer rates at ages 35-44, which is a good measure of recent smoking in the population, fell sharply from 1997 onward. During this period, revenues in real terms rose from about six to 12 billion euros. ${ }^{81}$ Tax levels stagnated from 2004 onward when Nicolas Sarkozy became finance minister as has the declines in per capita cigarette consumption. The decline in lung cancer was also due, more controversially, to replacement of high-tar with lower-tar cigarettes. ${ }^{82}$

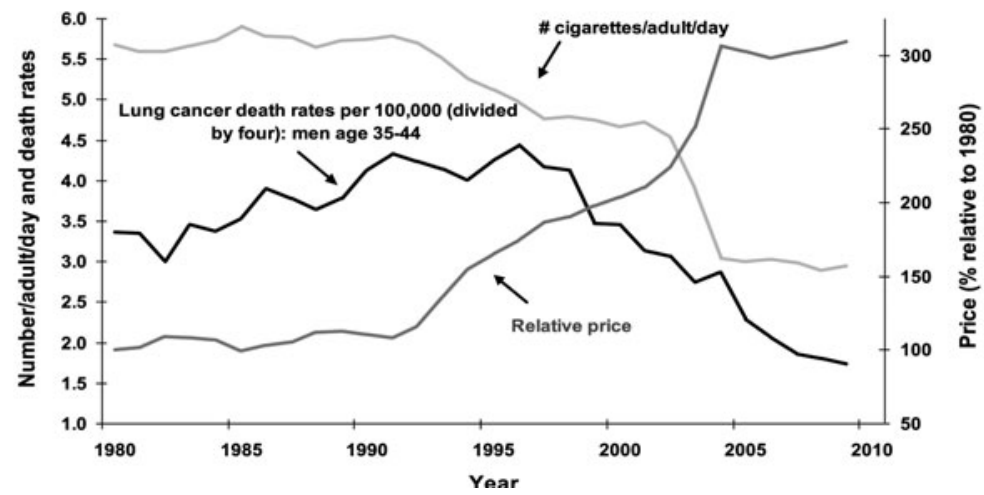

Fig. 8. France: smoking, tax and male lung cancer rates at young ages, 1980-2010. The per capita cigarette consumption, lung cancer death rates and relative price cigarettes are shown on the y-axes over time. Smoking per person per day and relative prices are provided by Catherine Hill. ${ }^{81}$ The lung-cancer death rates per 100,000 are divided by four, so as to enable these to be on the same scale as smoking amount per day. Female lung cancer rates peaked later than the males, but have also halted their rise as of 2002. ${ }^{43}$ The stabilisation of smoking prevalence in the 19801990 is due in part to the smaller earlier tax increases (Loi Veil) and to restrictions on advertising (Loi Evin). Further decreases in French smoking are reported after 2008, when bans on public smoking appeared. 
The following briefly reviews the effectiveness of interventions to reduce tobacco use at the population level. More detailed reviews are already published. ${ }^{1,5,68,69}$

\section{Tobacco taxation}

Higher taxation is the single most important intervention to raising global smoking cessation rates. Tobacco taxes and consumption are strongly inversely related worldwide. ${ }^{83-85}$ Well over 100 studies worldwide demonstrate that increases in taxes on cigarettes and other tobacco products lead to significant reductions in use. ${ }^{68,69,83-86}$ Studies from high-income countries estimate a ten percent increase in cigarette prices will reduce overall smoking by 2.5 percent to 5.0 percent in the medium term (within a few years), ${ }^{83,85}$ and perhaps twice this in the longer-term (5 years or longer) ${ }^{83}$ The few studies from low- and middle-income countries suggest an effect twice as great: a ten percent increase in price will reduce smoking by eight percent in the medium term. ${ }^{85}$ Higher taxes reduce relapse and decrease consumption among continuing smokers. Half or more of the effect of price on cigarette demand results from reducing the number of current smokers. ${ }^{87,88}$ Higher taxes increase the number of attempts at quitting smoking and the success of those attempts; a ten percent increase in price results in 11 percent to 13 percent shorter smoking duration or a three percent higher probability of cessation. ${ }^{89}$ Higher cigarette prices are particularly effective in preventing young smokers from moving beyond experimentation into regular, addicted smoking ${ }^{90}$ and among the less educated or lower-income individuals. ${ }^{91,92}$ This implies that tax increases will differentially reduce youth smoking in the future.

Affordability is a concept that captures the interaction between consumer's income level and tobacco prices. ${ }^{93}$ Typically, affordability is defined as gross income (GDP per capita relative to the wholesale price index for bidis or cigarettes). As price falls relative to income, affordability increases and vice versa. In India, bidis are nearly three times more affordable in 2011 than they were in 1990, while cigarettes are about 175 percent more affordable. ${ }^{30}$

High specific excise duties are far more likely to discourage switching between different types of tobacco products, are much easier to administer, and produce a much steadier stream of revenue. ${ }^{94}$ The exact impact of this excise duty structure would depend, of course, on the market conditions, industry efforts to counter the tax hike, and on large scale tax avoidance. Increases in excise duty decrease the differences between higher and lower priced cigarettes, effectively increasing the public health impact. The main 
weakness is that such excise duties need to adjust periodically for inflation, which is much higher in developing than in developed countries. Thus a complementary strategy is to raise the excise duty every year, in line with overall inflation and preferably in excess of inflation, such that the number of ex-smokers increases every year. Australia and New Zealand have opted to raise tax rates above inflation automatically, rather than necessitating annual increases through the usual channels. ${ }^{94}$ France pursued such an objective starting in 1991, and increased cigarette prices by five percent or more in excess of inflation. ${ }^{95}$ In high inflation settings, it might make sense to focus on affordability, in which case tobacco taxes would be increased by enough to raise prices above income growth so as to reduce affordability.

An increase in cigarette taxes of ten percent globally would raise cigarette tax revenues by nearly seven percent, as the fall in demand is less than proportional to the price increase in most countries. ${ }^{1,68,69}$ However, taxes are underused in most developing countries. ${ }^{96,97}$ Taxes tend to be absolutely higher and account for a greater share of the retail price ( $71 \%$ as of 2006) in high-income countries. In low- and middle-income countries, taxes account for 54 percent of the final price of cigarettes. ${ }^{97}$ In South Africa, tax as a percentage of retail price fell to about 20 percent around 1990 , but has subsequently risen to nearly 40 percent. ${ }^{86}$ As a result, consumption fell from about four cigarettes per adult per day to two over a decade. ${ }^{86,98}$ Poland's recent tax increases have doubled the real price of cigarettes $^{99}$ and dropped consumption. Mauritius and Mexico recently raised taxes by about 30 percent, which has already produced a drop in consumption.

A tax increase needed to raise the street prices of cigarettes by 70 percent would involve a two to 2.8 fold increase across countries. ${ }^{5}$ The increase would raise the street price for a pack of 20 cigarettes from about USD 0.7 to 1.3 in low-income countries, from about USD 1.3 to USD 2.3 in middle-income countries and from USD 3.7 to USD 6.3 in high-income countries. Such increases, while large, have been achieved in numerous countries, including Canada, France, Poland and South Africa and within the various states of the US. Indeed, price elasticity studies ${ }^{88}$ suggest that the 2.5 fold increase in the US federal cigarette tax as of 2009 (rising by 62 cents to USD 1.01/pack) might get about one million Americans to quit smoking and deter another two million youth from starting, thus saving over one million lives. ${ }^{5}$ 


\section{Health information and counter-advertising}

It is often assumed that the health consequences of tobacco are well known worldwide because over 40,000 studies on smoking and health have been published over the last five decades. ${ }^{8}$ While general knowledge of health risks may be high in developed populations, awareness of the hazards of smoking and benefits of cessation is low in China, India and other developing populations. ${ }^{100}$

In high-income countries, smokers are more aware of the risks, but most smokers minimise the personal relevance of these risks. ${ }^{101}$ Smoking patterns in western countries have changed in response to control policies and increased information. Data on tobacco hazards helps build public support to implement control measures, such as higher prices and bans on advertising and promotion. ${ }^{68,69}$ Decreases in smoking prevalence were largest in high-income countries where the public is constantly and consistently reminded of the dangers of smoking by extensive coverage of issues related to tobacco in the news media. ${ }^{1,100}$ For example, the 1962 report by the British Royal College of Physicians ${ }^{102}$ and the 1964 US Surgeon General's Report, ${ }^{103}$ in combination with the publicity that followed each publication, reduced consumption by four to nine percent initially, and by $15-30$ percent in the longer-term in both countries, and indeed in other countries, such as Switzerland. ${ }^{100,104}$ Thus, counteradvertising efforts, including focused mass publicity is likely to be effective in low- and middle-income countries. ${ }^{100}$ Prominent, rotating pictorial warning labels on tobacco products are effective at portraying risks to smokers, ${ }^{105}$ and would be particularly relevant where illiteracy is high (e.g., in India, half of the smoking deaths occur among the uneducated ${ }^{36}$ ).

\section{Restrictions on smoking in public places}

Restrictions on smoking in public places are intended chiefly to reduce non-smokers' exposure to passive tobacco smoke and also to create nonsmoking social norms. However, comprehensive restrictions also raise attempts to quit, so that overall consumption falls by three to four percent. ${ }^{106-108}$ Admissions for acute heart attack have fallen in several highincome settings who introduced restrictions on public smoking. ${ }^{108}$ Smoking bans in workplaces can reduce prevalence rates by up to 20 percent and reduce the quantity of cigarettes smoked among continuing smokers by five to 25 percent. ${ }^{108,109}$ These policies are most effective when strong social norms against smoking help to make smoking restrictions self-enforcing. ${ }^{110}$ 


\section{Bans on advertising and promotion}

Cigarettes are among the most heavily advertised and promoted products in the world. In 2005, cigarette companies spent USD 13.1 billion on advertising and promotion in the US alone; the highest spending level reported to date. ${ }^{111}$ In high-income countries, comprehensive bans reduce consumption by about seven percent, taking into account differences in price and non-price control interventions ${ }^{112}$ and may be twice as effective in low- and middle-income countries. ${ }^{113}$ However, partial bans have little effect, given that the tobacco industry shifts to other media or to promotion (such as rock concerts and web-based promotions).

\section{SMOKING CESSATION TREATMENTS}

Pharmacological treatments, including nicotine replacement therapies, bupropion, and varenicline, significantly improve the likelihood of quitting, with success rates two to three times those when pharmaceutical treatments are not employed. ${ }^{114}$ In addition, over-the-counter access to such medications increases access and decreases cost. ${ }^{115,116} \mathrm{~A}$ recent randomised trial in Poland found that cytisine, a cessation drug used commonly in the former socialist economies, was more effective than placebo for smoking cessation. ${ }^{117}$ As cytosine is much lower in price than standard drugs, it might be practicable in low and middle-income countries.

\section{Supply-side interventions}

In contrast to the effective interventions designed to reduce demand, there is scant evidence indicating that restricting supply can be an effective way to reduce consumption. Limiting youth access to tobacco products, crossborder trade restrictions, and crop substitution and diversification are mostly ineffective in reducing consumption, given that supply will always respond to demand. ${ }^{68,69}$ However, a key and effective intervention on the supply side is the control of smuggling. An estimated six to eight percent of cigarettes consumed globally are smuggled. ${ }^{118}$ The tobacco industry contributes to smuggling in order to reduce taxes and capture market share. ${ }^{119,120}$ Aside from harmonising prices between countries, effective measures to counter smuggling include prominent tax stamps and warning labels in local languages, better methods for tracking cigarettes through the distribution chain, aggressive enforcement of anti-smuggling laws, and stronger penalties. ${ }^{120,121}$ Even in the presence of smuggling, tax increases will reduce consumption and increase revenue. ${ }^{118}$ 


\section{THE FRAMEWORK CONVENTION ON TOBACCO CONTROL}

The main vehicle to accelerate tobacco control is the World Health Organization's Framework Convention on Tobacco Control (FCTC), which is the first ever global treaty on public health. This convention has been signed by over 160 countries. ${ }^{122}$ The FCTC has specific provisions for introduction of each of the evidence-based strategies noted above, in part as its formulation was driven by evidence from two major reviews of global tobacco control. ${ }^{68,69}$ More recently, the UN held a high level summit on non-communicable diseases, which included discussion about the importance of action on tobacco control. ${ }^{123}$

The main limitation of the FCTC is that it is a statement mostly of intent, and the specific actions needed to implement the provisions in each country require ongoing support for tobacco control. ${ }^{124}$ In particular, the implementation of higher tobacco taxes is the top priority, but demand considerable efforts to mobilize finance ministries, and not only health ministries. FCTC tax policy implementation needs to consider also the active influence of the tobacco industry, which seeks to make complex tax regimes which favour certain segments of the tobacco market, ${ }^{30}$ as well as outright lobbying to confuse governments on tobacco taxes. ${ }^{125}$ More recently, the Bloomberg Philanthropies and the Bill and Melinda Gates Foundation have pledged, collectively, over 500 million USD to global tobacco control. If these funds are spent well, and focused on the above cost-effective interventions, then a substantial numbers of deaths might be avoided in the next few decades as a result of increased adult cessation, and even more deaths avoided in the second half of the $21^{\text {st }}$ century from avoidance of increases in youth smoking. ${ }^{126}$

\section{CONCLUSION: AVOIDABLE TOBACCO DEATHS BEFORE 2050}

Earlier estimates have examined the potential impact of a 70 percent price increase and a ten percent reduction from nonprice interventions such as bans on public smoking or information measures among the cohort of 1.1 billion smokers alive in $2000 .{ }^{5}$ Price increases have the greatest impact on future tobacco mortality; a 70 percent higher price would prevent more than 110 million deaths, or one-quarter of all expected premature deaths from tobacco worldwide. Of avoided deaths, about 25 million would be from cancer and 50 million would be from vascular disease. Nonprice interventions would prevent 35 million deaths. The greatest impact of these tobacco control interventions would occur after 2015, but a substantial 
number of deaths could be avoided even prior to then. By 2030 to 2035, the expected annual toll of ten million deaths could be reduced to about seven million.

In sum, on current smoking patterns, about one billion people will be killed in the $21^{\text {st }}$ century by smoking. Without widespread cessation, about 400 million people alive today will be killed by smoking between 2010 and 2050. At least half will die at ages 30-69 years, losing decades of productive life, and those who smoke throughout adult life can expect to lose about one decade of life compared to non-smokers. Smoking-attributable cancer and total deaths have fallen sharply in high-income countries but will rise globally unless today's smokers, most of whom live in low- and middleincome countries, quit smoking before or during middle age. Tripling taxes on tobacco could rapidly raise cessation rates and deter smoking initiation. Higher taxes, increased regulations on smoking, and improved information for consumers could prevent at least 110 million smoking deaths in the next few decades.

\section{Acronyms List:}

FCTC $=$ World Health Organization's Framework Convention on Tobacco Control

Additional Material: Additional information on tobacco hazards in India, China, and developed countries (including updated results to 2005 on the UK, US and Poland) may be found at URLs: http://www.cghr.org/ and http://www.ctsu.ox.ac. uk/deathsfromsmoking/ (accessed 31 August 2012).

Acknowledgments: This paper is a modified version of that published in 2009 in Nature Cancer Reviews ${ }^{5}$ (with permission). I am very grateful to Krishna Palipudi and Samira Asma for comments, careful edits and assistance on the GATS data. I also thank Catherine Hill, Richard Peto and Michael Thun for providing access to various mortality data and smoking estimates. The views represented are not necessarily those of the institutions with which the authors are affiliated. Support: Fogarty International Centre (grant R01 TW007939-01), the Dalla Lana School of Public Health, and the Bill and Melinda Gates Foundation.

Dedication: This paper is dedicated to the late Sir Richard Doll (1912-2005), who would have turned 100 on October 28, 2012. ${ }^{29}$

Conflicts of Interest: Prabhat Jha receives funding from the Bill and Melinda Gates Foundation and the US National Institutes for Health for tobacco epidemiology and control. 


\section{REFERENCES:}

1. Jha P, Chaloupka FJ, Moore J, Gajalakshmi V, Gupta PC, Peck R, et al. Tobacco addiction. In: Disease Control Priorities in Developing Countries. Jamison DT, Breman JG, Measham AR, et al., (editors). New York, NY: Oxford University Press; 1996. p.869-86.

2. Ezzati M, Lopez AD. Regional, disease specific patterns of smoking-attributable mortality in 2000. Tob Control. 2004;13:388-95.

3. Ezzati M, Henley SJ, Lopez AD, Thun MJ. Role of smoking in global and regional cancer epidemiology: current patterns and data needs. Int J Cancer. 2005;116:963-71.

4. World Health Organization. MPOWER: A Policy Package to Reverse the Tobacco Epidemic. Geneva: WHO; 2011.

5. Jha P. Avoidable global cancer deaths and total deaths from smoking. Nat Rev Cancer. 2009;9:655-64.

6. Peto R, Lopez AD. The future worldwide health effects of current smoking patterns. In: Critical Issues in Global Health. Koop EC, Pearson CE, Schwarz MR, (editors). New York, NY; Jossey-Bass: 2001.

7. World Health Organization. Tobacco or health: a Global Status Report. Geneva: WHO; 1997.

8. International Agency for Research on Cancer. IARC Monographs on the Evaluation of the Carcinogenic Risks of Chemicals to Humans. Vol. 83: Tobacco Smoke and Involuntary Smoking. Lyon, France: IARC; 2004.

9. US Department of Health and Human Services. Reducing the Health Consequences of Smoking: 25 Years of Progress: A Report of the Surgeon General. Center for Chronic Disease Prevention and Health Promotion, Office on Smoking and Health; 1989.

10. International Agency for Research on Cancer. IARC Monographs on the Evaluation of the Carcinogenic Risks of Chemicals to Humans. Vol. 89: Smokeless Tobacco and Some Tobacco-Specific n-Nitrosamines. Lyon, France: IARC; 2007.

11. US Department of Health and Human Services. Reducing Tobacco Use: A Report of the Surgeon General. Atlanta, GA: US DHHS, Public Health Service, Centers for Disease Control, Center for Chronic Disease Prevention and Health Promotion, Office on Smoking and Health; 2000.

12. US Department of Health and Human Services. Health Consequences of Involuntary Exposure to Tobacco Smoke. US DHHS; 2006.

13. United Nations. World Population Prospects: the 2010 Revision. Updated 20 October 2011. Available from URL: http://esa.un.org//unpd/wpp/index.htm (accessed 31 August 2012).

14. World Health Organization, Country Office for Bangladesh. Global Adult Tobacco Survey: Bangladesh Report 2009. Bangladesh: WHO; 2009. Available from URL: http://www.who.int/tobacco/surveillance/gats_ bangladesh/en/index.html (accessed 31 August 2012). 
15. Instituto Nacional de Câncer (Brasil). Global Adult Tobacco Survey Brazil Report 2008. Rio de Janeiro: INCA; 2010. Available from URL: http://www. who.int/tobacco/surveillance/en_tfi_gats_2010_brazil.pdf (accessed 31 August 2012).

16. GATS China. Global Adult Tobacco Survey. Fact Sheet China: 2010. Available from URL: http://www.who.int/tobacco/surveillance/gats_china/en/index. html (accessed 31 August 2012).

17. Central Agency for Public Mobilization and Statistics. Ministry of Health, Egypt. Global Adult Tobacco Survey (GATS) Egypt Country Report 2009. World Health Organization; 2010. Available from URL: http://www.who.int/ tobacco/surveillance/gats_egypt/en/index.html (accessed 31 August 2012).

18. International Institute for Population Sciences, Ministry of Health and Family Welfare, Government of India. Global Adult Tobacco Survey India (GATS) India Report 2009-2010. World Health Organization; 2010. Available from URL: http://www.whoindia.org/en/Section20/Section25_1861.htm (accessed 31 August 2012).

19. Ministry of Health, Mexico. Encuesta Global de Tabaquismo en Adultos, México 2009. Washington, DC: Pan American Health Organization; 2010. Available from URL: http://www.who.int/tobacco/surveillance/gats_rep_ mexico.pdf (accessed 31 August 2012). [In Spanish].

20. GATS Philippines. Philippines Global Adult Tobacco Survey Country Report 2010. Available from URL: http://www.who.int/tobacco/surveillance/gats_ philippines/en/index.html (accessed 31 August 2012).

21. Ministry of Health, Poland. Global Adult Tobacco Survey Poland 2009-2010. Ministry of Health, Poland; 2010. Available from URL: http://www.who.int/ tobacco/surveillance/en_tfi_gats_poland_report_2010.pdf (accessed 31 August 2012).

22. GATS Russian Federation. Global Adult Tobacco Survey Russian Federation 2009. Available from URL: http://www.who.int/tobacco/surveillance/en_tfi_ gats_russian_countryreport.pdf (accessed 31 August 2012).

23. World Health Organization, Regional office for South East Asia. Global Adult Tobacco Survey: Thailand Country Report. Thailand: WHO; 2009. Available from URL: http://www.who.int/tobacco/surveillance/thailand_gats_report_ 2009.pdf (accessed 31 August 2012).

24. The Ministry of Health of Turkey. Global Adult Tobacco Survey Turkey Report 2010. Turkey: Ministry of Health; 2010. Available from URL: http://www. havanikoru.org.tr/Docs_Tutun_Dumaninin_Zararlari/GATS.pdf (accessed 31 August 2012).

25. GATS Ukraine. Global Adult Tobacco Survey (GATS) Report Ukraine 2010. Ukraine: 2010. Available from URL: http://www.who.int/tobacco/ surveillance/en_tfi_gats_ukraine_report_2010.pdf (accessed 31 August 2012). 
26. GATS Uruguay. Global Adult Tobacco Survey Uruguay (GATS) Fact Sheet Uruguay 2009. February 2010. Available from URL: http://www.who.int/ tobacco/surveillance/gats_uruguay/en/index.html (accessed 31 August 2012).

27. Ministry of Health Of Viet Nam, Hanoi Medical University, General Statistics Office, Centers for Disease Control and Prevention, World Health Organization. Global Adult Tobacco Survey (GATS) Viet Nam 2010. Hanoi: 2010. Available from URL: http://www.who.int/tobacco/surveillance/en_tfi_ gats_vietnam_report.pdf (accessed 31 August 2012).

28. Warren CW, Jones NR, Eriksen MP, Asma S; Global Tobacco Surveillance System (GTSS) collaborative group. Patterns of global tobacco use in young people and implications for future chronic disease burden in adults. Lancet. 2006;367:749-53.

29. International Smoking Statistics. A Collection of Historical Data from 30 Economically Developed Countries. Forey B, Hamling J, Lee P, (editors). New York, NY: Oxford University Press; 2009.

30. Jha P, Guindon E, Joseph RA, Nandi A, John RM, Rao K, et al. A rational taxation system of bidis and cigarettes to reduce smoking deaths in India. Econ Polit Wkly. 2011;46:44-51.

31. Monteiro CA, Cavalcante TM, Moura EC, Claro RM, Szwarcwald CL. Population-based evidence of a strong decline in the prevalence of smokers in Brazil (1989-2003). Bull World Health Organ. 2007;85:527-34.

32. Jha P, Ranson MK, Nguyen SN, Yach D. Estimates of global and regional smoking prevalence in 1995, by age and sex. Am J Public Health. 2002; 92:1002-6.

33. Peto R, Darby S, Deo H, Silcocks P, Whitley E, Doll R. Smoking, smoking cessation, and lung cancer in the UK since 1950: combination of national statistics with two case-control studies. BMJ. 2000;321:323-9.

34. Chinese Academy of Preventive Medicine, Smoking in China: 1996 National Prevalence Survey of Smoking Pattern. Beijing: Science and Technology Press; 1997.

35. Jenkins CN, Dai PX, Ngoc DH, Kinh HV, Hoang TT, et al. Tobacco use in Vietnam. Prevalence, predictors, and the role of the transnational tobacco corporations. JAMA. 1997;277:1726-31.

36. Jha P, Jacob B, Gajalakshmi V, Gupta PC, Dhingra N, Kumar R, et al. A nationally representative case-control study of smoking and death in India. $\mathrm{N}$ Engl J Med. 2008;358:1137-47.

37. Sample Registration System Baseline Survey Report, 2004. New Delhi: Registrar General of India; 2007.

38. The hazards of smoking and the benefits of stopping. In: IARC Handbooks of Cancer Prevention. Tobacco control. Vol. 11: Reversal of risk after quitting smoking. Dresler C, Leon M, (editors). Lyon: International Agency for Research on Cancer; 2007. p.15-27.

39. Doll R, Peto R. The causes of cancer: quantitative estimates of avoidable risks of cancer in the United States today. J Natl Cancer Inst. 1981;66:1191-308. 
40. Doll R, Peto R, Boreham J, Sutherland I. Mortality in relation to smoking: 50 years' observations on male British doctors. BMJ. 2004;328:1519.

41. Doll R, Peto R, Wheatley K, Gray R, Sutherland I. Mortality in relation to smoking: 40 years' observations on male British doctors. BMJ. 1994;309:901-11.

42. Thun, MJ, Henley SJ, Calle EE. Tobacco use and cancer: an epidemiologic perspective for geneticists. Oncogene. 2002;21:7307-25.

43. Peto R, Lopez AD, Boreham J, Thun M. Mortality from Smoking in Developed Countries, 1950-2000. 3rd ed. 2009.

44. Peto R, Lopez AD, Boreham J, Thun M, Heath C Jr. Mortality from tobacco in developed countries: indirect estimation from national vital statistics. Lancet. 1992;339:1268-78.

45. Peto R, Lopez AD, Boreham J, Thun M and Heath Jr C. Mortality from Smoking in Developed Countries, 1950-2000. Oxford: Oxford University Press; 1994.

46. Liu BQ, Peto R, Chen ZM, Boreham J, Wu YP, Li JY, et al. Emerging tobacco hazards in China: 1. Retrospective proportional mortality study of one million deaths. BMJ. 1998;317:1411-22.

47. Niu SR, Yang GH, Chen ZM, Wang JL, Wang GH, He XZ, et al. Emerging tobacco hazards in China: 2. Early mortality results from a prospective study. BMJ. 1998;317:1423-4.

48. Zatonski W, Jha P. The Health Transformation in Eastern Europe after 1990: A Second Look. Warsaw: Marie Skeodowska-Curie Cancer Center and Institute of Oncology; 2000.

49. Crispo A, Brennan P, Jöckel KH, Schaffrath-Rosario A, Wichmann HE, Nyberg $\mathrm{F}$, et al. The cumulative risk of lung cancer among current, ex- and neversmokers in European men. Br J Cancer. 2004;91:1280-6.

50. Lopez AD, Mathers CD, Ezzati M, Jamison DT, Murray CJL. The Global Burden of Disease and Risk Factors. Washington, DC, and New York, NY: World Bank and Oxford University Press; 2006.

51. Gu D, Kelly TN, Wu X, Chen J, Samet JM, Huang JF, et al. Mortality attributable to smoking in China. N Engl J Med. 2009;360:150-9.

52. Dikshit R, Gupta PC, Ramasundarahettige C, Gajalakshmi V, Aleksandrowicz $\mathrm{L}$, Badwe R, et al. Cancer mortality in India: a nationally representative mortality survey. Lancet. 2012;379:1807-16.

53. Plummer M, Herrero R, Franceschi S, Meijer CJ, Snijders P, Bosch FX, et al. Smoking and cervical cancer: pooled analysis of the IARC multi-centric case-control study. Cancer Causes Control. 2003;14:805-14.

54. Jha P, et al. Evidence-based Cardiology. Yusuf S, et al., (editors). Oxford: Oxford University Press; 2009.

55. Teo KK, Ounpuu S, Hawken S, Pandey MR, Valentin V, Hunt D, et al. Tobacco use and risk of myocardial intraction in 52 countries in the INTERHEART study: a case-control study. Lancet. 2006;368:647-58.

56. Smith KR, Mehta S. The burden of disease from indoor air pollution in developing countries: comparison of estimates. Int J Hyg Environ Health. 2003;206:279-89. 
57. Doll R, Hill AB. Mortality in relation to smoking: ten years' observations of British doctors. Br Med J. 1964;1:1460-7 CONCL.

58. Gupta PC, Pednekar MS, Parkin DM, Sankaranarayanan R. Tobacco associated mortality in Mumbai (Bombay) India. Results of the Bombay Cohort Study. Int J Epidemiol. 2005;34:1395-402.

59. Gajalakshmi V, Peto R, Kanaka TS, Jha P. Smoking and mortality from tuberculosis and other diseases in India: retrospective study of 43000 adult male deaths and 35000 controls. Lancet. 2003;362:507-15.

60. Thun MJ, Apicella LF, Henley SJ. Smoking vs other risk factors as the cause of smoking-attributable deaths: confounding in the courtroom. JAMA. 2000; 284:706-12.

61. Rostron B. Smoking-attributable mortality in the United States. Epidemiology. 2011;22:350-5.

62. Jha P, Peto R, Zatonski W, Boreham J, Jarvis MJ, Lopez AD. Social inequalities in male mortality, and in male mortality from smoking: indirect estimation from national death rates in England and Wales, Poland, and North America. Lancet. 2006;368:367-70.

63. Peto R, Whitlock G, Jha P. Effects of Obesity and Smoking on U.S. Life Expectancy N Engl J Med. 2010;362:855-7.

64. Prospective Studies Collaboration. Body-mass index and cause-specific mortality in 900,000 adults: collaborative analyses of 57 prospective studies. Lancet. 2009;373:1083-96

65. Finkelstein EA, Trogdon JG, Cohen JW, Dietz W. Annual medical spending attributable to obesity: payer-and service-specific estimates. Health Aff (Millwood). 2009;28:w822-31.

66. Mathers CD, Loncar D. Projections of global mortality and burden of disease from 2002 to 2030. PLoS Med. 2006;3:e442.

67. The Economist. Tobacco and tolerance. 20 December 1997. p.59-61.

68. Jha P, Chaloupka FJ. Curbing the Epidemic: Governments and the Economics of Tobacco Control. Washington DC: World Bank; 1999.

69. Jha P, Chaloupka FJ. Tobacco Control in Developing Countries. Oxford: Oxford University Press; 2000.

70. Jha P, Musgrove P, Chaloupka FJ, Yurkeli A. The Economic rationale for intervention in the tobacco market. In: Tobacco Control in Developing Countries. Jha P, Chaloupka FJ, (editors). Oxford and New York, NY: Oxford University Press; 2000. p.153-74.

71. US Department of Health and Human Services. The health consequences of smoking: the changing cigarette. A report of the Surgeon General. Washington, DC: US DHHS, Centers for Disease Control and Prevention; 2001.

72. Lightwood J, Collins D, Lapsley H, et al. Estimating the costs of tobacco use. In: Tobacco Control in Developing Countries. Jha P, Chaloupka FJ, (editors). Oxford and New York, NY: Oxford University Press; 2000. 
73. John RM, Sung HY, Max W. Economics cost of tobacco use in India, 2004. Tob Control. 2009;18:138-43.

74. Little International Inc. Public finance balance of smoking in the Czech Republic. 2000. URL: http://tobaccofreekids.org/reports/philipmorris/ pmczechstudy.pdf (viewed 5 July 2011).

75. John RM, Sung HY, Max WB, Ross H. Counting 15 million more poor in India, thanks to tobacco. Tob Control. 201;20:349-52.

76. Rani M, Bonu S, Jha P, Nguyen SN, Jamjoum L. Tobacco use in India: prevalence and predictors of smoking and chewing in a national cross sectional household survey. Tob Control. 2003;12:e4.

77. John RM. Crowding out effect of tobacco expenditure and its implications on household resource allocation in India. Soc Sci Med. 2008;66:1356-67.

78. Peck R, et al. An analyes of the economic welfare from tobacco use. In: Tobacco Control in Developing Countries. Jha P, Chaloupka FJ, (editors). Oxford and New York, NY: Oxford University Press; 2000. p.211-21.

79. Gruber J, Mullainathan S. Do cigarette taxes make smokers happy? Adv Econ Anal Pol. 2005;5:Article 4.

80. Hamilton WL, Biener L, Rodger CN. Who supports tobacco excise taxes? Factors associated with town's and individual's support in Massachusetts. J Public Health Manag Pract. 2005;11:333-40.

81. Hill C, Jougla E, Beck F. Prévention et facteurs de risque. Institut de cancérologie Gustave Roussy. 2010. Available from URL: http://www.igr.fr/fr/page/ prevention-et-facteurs-de-risque_80 (accessed 3 September 2012). [In French]

82. Harris JE, Thun MJ, Mondul AM, Calle EE. Cigarette tar yields in relation to mortality from lung cancer in the cancer prevention study II prospective cohort, 1982-8. BMJ. 2004;328:72.

83. Chaloupka FJ, Tauras JA, Grossman M. The economics of addiction. In: Tobacco Control in Developing Countries. Jha P, Chaloupka FJ, (editors). Oxford and New York, NY: Oxford University Press; 2000.

84. Chaloupka FJ, Warner KE. The economics of smoking. In: The Handbook of Health Economics. Newhouse J, Culyer A, (editors). Amsterdam: Elsevier Science; 2000.

85. Chaloupka FJ, et al. The taxation of tobacco products. In: Tobacco Control in Developing Countries. Jha P, Chaloupka FJ, (editors). Oxford and New York, NY: Oxford University Press; 2000.

86. Van Walbeek C. Tobacco control in South Africa. Promot Educ. 2005;Suppl $4: 25-8,57$.

87. Wasserman J, Manning WG, Newhouse JP, Winkler JD. The effects of excise taxes and regulations on cigarette smoking. J Health Econ. 1991;10:43-64.

88. Tauras JA, Chaloupka FJ. Impact of tobacco control spending and tobacco control policies on adolescents' attitudes and beliefs about cigarette smoking. Evidence Based Preventive Medicine. 2004;1:111-20. 
89. Tauras JA. The Transition to Smoking Cessation: Evidence from Multiple Failure Duration Analysis: NBER Working Paper No. 7412. Cambridge, MA: National Bureau of Economic Research; 1999.

90. Emery S, White MM, Pierce JP. Does cigarette price influence adolescent experimentation? J Health Econ. 2001;20:261-70.

91. Centers for Disease Control and Prevention (CDC). Response to increases in cigarette prices by race/ethnicity, income, and age groups--United States, 1976-1993. MMWR Morb Mortal Wkly Rep. 1998;47:605-9.

92. Townsend J, Roderick P, Cooper J. Cigarette Smoking by Socio-Economic Group, Sex, and Age: Effects of Price, Income, and Health Publicity. BMJ. 1998;309:923-6.

93. Blecher EH, van Walbeek CP. An international analysis of cigarette affordability. Tob Control. 2004;13:339-46.

94. World Health Organization. WHO Technical Manual on Tobacco Tax Administration. Geneva: WHO; 2010.

95. Recours A. Politique de santé et Fiscalité du tabac. Rapport à Monsieur le Premier Ministre. Septembre 1999. [In French]

96. Guindon E, Bettcher D. Tobacco control in tobacco-producing countries. Bull World Health Organ. 2001;79:1086.

97. IARC Handbooks of Cancer Prevention. Effectiveness of Tax and Price Policies for Tobacco Control, Vol 14. 2011.

98. Eberlee J. South Africa's Winning Tobacco Control Strategy. The International Development Research Center Reports, 2001.

99. Ciecierski C. Tobacco control and the transitional economies of Europe: aspects of taxation in Poland. In: 12th World Conference on Tobacco OR Health: Global Action for a Tobacco Free Future 2003.

100. Kenkel D, Chen L. Consumer information and tobacco use. In: Tobacco Control in Developing Countries. Jha P, Chaloupka FJ, (editors). Oxford and New York, NY: Oxford University Press; 2000.

101. Weinstein ND. Accuracy of smokers' risk perceptions. Ann Behav Med. 1998;20:135-40.

102. UK Medical Research Council. Smoking and Health: Summary and Report of the Royal College of Physicians of London on Smoking in Relation to Cancer of the Lung and Other Diseases. London: UKMRC; 1962.

103. US Department of Health, Education and Welfare. Smoking and Health: Report of the Advisory Committee to the Surgeon General of the Public Health Service. US Department of Health, Education, and Welfare, Public Health Service, Center for Disease Control; 1964.

104. Townsend J. Policies to halve smoking deaths. Addiction. 1993;88:37-46.

105. Hammond D, Fong GT, McNeill A, Borland R, Cummings KM. Effectiveness of cigarette warning labels in informing smokers about the risks of smoking: findings from the International Tobacco Control (ITC) Four Country Survey. Tob Control. 2006;15 Suppl 3:iii19-25. 
106. McNabola A, Gill LW. The control of environmental tobacco smoke: a policy review. Int J Environ Res Public Health. 2009;6:741-58.

107. Bauer JE, Hyland A, Li Q, Steger C, Cummings KM. A longitudinal assessment of the impact of smoke-free worksite policies on tobacco use. Am J Public Health. 2005;95:1024-9.

108. Fichtenberg CM, Glantz SA. Effect of smoke-free workplaces on smoking behaviour: systematic review. BMJ. 2002;325:188.

109. Levy DT, Friend K, Polishchuk E. Effect of clean indoor air laws on smokers: the clean air module of the SimSmoke computer simulation model. Tob Control. 2001;10:345-51.

110. Jacobson PD, Wasserman J. Tobacco Control Laws: Implementation and Enforcement. Santa Monica, CA: RAND; 1997.

111. Cigarette Report for 2004 and 2005. 2007, Washington, D.C.: Federal Trade Commission.

112. Saffer H, Chaloupka FJ. Tobacco advertising: economic theory and international evidence. J Health Econ. 2000;19:1117-37.

113. Blecher E. The impact of tobacco advertising bans on consumption in developing countries J Health Econ. 2008;27:930-42.

114. US Department of Health and Human Services. Health Consequences of Smoking: Nicotine Addiction. A Report of the Surgeon General. USDHHS; 1988.

115. Eisenberg MJ, Filion KB, Yavin D, Bélisle P, Mottillo S, Joseph L, et al. Pharmacotherapies for smoking cessation: a meta-analysis of randomized controlled trials. CMAJ 2008;179:135-44.

116. Silagy C, et al. Nicotine Replacement Therapy for Smoking Cessation (Cochrane Review). In: The Cochrane Library, Issue 4. Oxford: Update Software; 2004.

117. West R, Zatonski W, Cedzynska M, Lewandowska D, Pazik J, Aveyard P, Stapleton J. Placebo-Controlled Trial of Cytisine for Smoking Cessation. N Engl J Med. 2011;365:1193-200.

118. Merriman D, Yurekli A, Chaloupka FJ. How big is the worldwide cigarette smuggling problem?, In: Tobacco Control in Developing Countries. Jha P, Chaloupka FJ, (editors). Oxford and New York, NY: Oxford University Press; 2000.

119. Joossens L, et al. Issues in the Smuggling of Tobacco Products. In: Tobacco Control in Developing Countries. Jha P, Chaloupka FJ, (editors). Oxford and New York, NY: Oxford University Press; 2000.

120. Joossens L, Raw M. Turning off the tap: the real solution to cigarette smuggling. Int J Tuberc Lung Dis. 2003;7:214-22.

121. Joossens L, Raw M. Progress in combating cigarette smuggling: controlling the supply chain. Tob Control, 2008;17:399-404.

122. Liberman J. Four COPs and counting: achievements, underachievements and looming challenges in the early life of the WHO FCTC Conference of the Parties. Tob Control. 2012;21:215-20. 
123. Beaglehole R, Bonita R, Horton R, Adams C, Alleyne G, Asaria P, et al. for the NCD Alliance. Priority actions for the non-communicable disease crisis. Lancet. 2011;377:1438-47

124. Jha P, Paccaud F, Nguyen S. Strategic priorities in tobacco control for governments and international agencies. In: Tobacco Control in Developing Countries. Jha P, Chaloupka FJ, (editors). Oxford and New York, NY: Oxford University Press; 2000. p. 449-64.

125. Mamudu HM, Hammond R, Glantz S. Tobacco industry attempts to counter the World Bank report Curbing the Epidemic and obstruct the WHO framework convention on tobacco control. Soc Sci Med. 2008;67:1690-9.

126. Jha P, Nugent R, Verguet S, Bloom DE, Hum R. Chronic Diseases. Copenhagen: Consensus Challenge Paper; 2012. Available from URL: http://www. copenhagenconsensus.com/Projects/CC12/Research/ChronicDisease.aspx (accessed 3 September 2012).

127. Thun MJ, Hannan LM, Adams-Campbell LL, Boffetta P, Buring JE, Feskanich D, et al. Lung Cancer Occurrence in Never-Smokers: An Analysis of 13 Cohorts and 22 Cancer Registry Studies. PLoS Med. 2008;5:e185.

128. Sun S, Schiller JH, Gazdar AF. Lung cancer in never smokers-a difference disease. Nat Rev Cancer. 2007;7:778-90.

129. Peto R, Beral V. Sir Richard Doll CH OBE. 28 October 1912 - 24 July 2005. Biogr Mems Fell R Soc. 2010;56:63-83. Available from URL: http:// rsbm.royalsocietypublishing.org/content/56/63.full.pdf+html (accessed 3 September 2012). 